\title{
STUDI ANALISIS PENGARUH LENDUTAN AKIBAT GESER PADA BALOK KAYU
}

\author{
Buen Sian \\ Dosen Jurusan Teknik Sipil, Fakultas Teknik, Universitas Katolik Parahyangan \\ Jalan Ciumbuleuit 94, Bandung, 40141 \\ E-mail: buensian@unpar.ac.id ; songbunsian@gmail.com
}

\begin{abstract}
ABSTRAK
Lendutan pada struktur sering kali disebabkan oleh gaya dalam seperti momen lentur, gaya geser, atau gaya normal. Pada umumnya metode untuk menentukan lendutan balok hanya mempertimbangkan lendutan yang diakibatkan oleh momen lentur saja. Lendutan akibat gaya geser biasanya diabaikan dalam analisa struktur. Pada kenyataan pengaruh lendutan geser cukup signifikan untuk diperhitungkan terutama pada konstruksi kayu. Kayu digambarkan sebagai material orthotropik dan mempunyai keunikan sifat mekanik pada arah ketiga sumbu yang saling tegak lurus yaitu: sumbu longitudinal L yang sejajar serat kayu, sumbu radial R, dan sumbu tangensial T. Kayu mempunyai tiga modulus elastisitas $\mathrm{E}_{\mathrm{L}}, \mathrm{E}_{\mathrm{R}}$, dan $\mathrm{E}_{\mathrm{T}}$ serta tiga modulus geser $G$, pada perhitungan lendutan $E_{L}$ dan $G_{L}$ digunakan. Pertama pengaruh geser terhadap lendutan total dihitung berdasarkan 34 jenis kayu, hasilnya menunjukan bahwa pengaruh lendutan geser menjadi kecil pada balok bentang panjang. Untuk beberapa jenis kayu pengaruh geser masih ada meskipun pada panjang bentang 4m. Kemudian dilakukan perhitungan selanjutnya untuk mendapatkan beberapa diagram dengan variasi pada: rasio modulus geser/modulus elastisitas, panjang balok, dan berbagai penampang. Diagram hasil studi ini dapat digunakan untuk semua jenis kayu untuk mendapatkan kontribusi lendutan geser terhadap lendutan total.
\end{abstract}

Kata Kunci: deformasi, momen lentur, geser, orthotropik.

\begin{abstract}
Most often the deflection of a structure is caused by internal loadings such as bending moment, shear force, or normal force. Generally the method for determining deflection of a beam considers only deflections due to bending. Deflection due to shear is usually neglected in structural analysis. In fact the influence of shear deflection is significant, especially in wood structure. Wood may be described as an orthotropic material, it has unique mechanical properties in the directions of three mutually perpendicular axis: longitudinal $L$, radial $R$, and tangential $T$. Wood has three moduli of elasticity $E$ which are denoted by $\mathrm{E}_{\mathrm{L}}, \mathrm{E}_{\mathrm{R}}$, and $\mathrm{E}_{\mathrm{T}}$, three moduli of rigidity $G$ and the deflection was calculated based on $\mathrm{E}_{\mathrm{L}}$ and $\mathrm{G}_{\mathrm{L}}$. First the contribution of shear deformation to the total deflection was calculated based on 34 wood properties. The results showed that the influence of the shear deflection was small at long span. For some wood species the effect will not lost at span length $4 \mathrm{~m}$. Afterwards some analitycal study was done to find some diagrams with variation of $G / E$, span length, and cross section. These diagrams can be used for all wood species to find the contribution of shear deformation to total deflection.
\end{abstract}

Keywords: deformation, bending moment, shear, orthotropic.

\section{PENDAHULUAN}

Lendutan balok dipengaruhi oleh gaya dalam seperti momen, geser, normal, dan torsi tetapi perhitungan lendutan pada umumnya hanya memperhitungkan akibat momen saja sedangkan gaya geser, normal, dan torsi tidak diperhitungkan karena harganya 
dianggap kecil dan dapat diabaikan. Memperhitungkan lendutan akibat gaya geser pada analisis struktur kayu di Indonesia masih jarang dilakukan. Bahkan beberapa literatur struktur kayu mengasumsikan pengaruh lendutan akibat gaya geser hanya sebesar 10\%, padahal harga sesungguhnya cukup besar dan tidak bisa diabaikan terutama kalau kayu tersebut pendek. Hal ini bisa disebabkan belum banyaknya penelitian yang menghasilkan besarnya modulus geser untuk kayu luar maupun yang ada di Indonesia.

Kayu berasal dari tumbuhan yang terdiri dari serat-serat dengan arah tertentu, susunan serat-serat inilah yang mempengaruhi sifat kayu. Kayu bersifat orthotropis dengan tiga sumbu simetri yaitu sumbu longitudinal (searah serat), sumbu radial (tegak lurus lingkaran tumbuh), dan sumbu tangensial (menyinggung lingkaran tumbuh). Pada umumnya perbedaan sifat kayu lebih ditentukan oleh arah sejajar serat dan arah tegak lurus serat sedangkan pada arah radial dan tangensial biasanya sangat kecil dan seringkali diabaikan. Berbeda dengan beton dan baja merupakan material isotropik yang mempunyai satu besaran modulus elastisitas dan modulus geser, tapi kayu mempunyai tiga modulus elastisitas yaitu, $\mathrm{E}_{\mathrm{L}}, \mathrm{E}_{\mathrm{R}}$, dan $\mathrm{E}_{\mathrm{T}}$ serta tiga modulus geser $\mathrm{G}$. Perhitungan lendutan pada kayu diambil searah dengan sumbu longitudinal atau sejajar serat sehingga dalam perhitungan modulus yang digunakan adalah $E_{L}$ dan $G_{L}$.

Mengingat besarnya pengaruh gaya geser pada lendutan dalam analisis struktur kayu, perlu dihitung seberapa besar pengaruhnya untuk berbagai bentuk penampang dan panjang balok. Berdasarkan data 31 jenis kayu luar dan tiga jenis kayu Indonesia yang sudah diketahui harga modulus elastisitas (5500MPa-14868MPa) dan modulus gesernya (396 MPa-1257MPa), dihitung secara analitis dengan bantuan MathCAD ,berapa persen pengaruh lendutan akibat gaya geser terhadap lendutan totalnya. Lendutan dihitung di tengah bentang terhadap balok di atas dua perletakan dengan beban terpusat di tengahnya. Penampang balok dengan variasi: (1) Penampang persegi panjang dengan tinggi $10 \mathrm{~cm}$ $40 \mathrm{~cm}$. (2) Penampang I dengan tinggi $20 \mathrm{~cm}, 30 \mathrm{~cm}$, dan $40 \mathrm{~cm}$ serta tinggi web 0,6 terhadap tinggi penampangnya. (3) Penampang I dengan tinggi $20 \mathrm{~cm}, 30 \mathrm{~cm}$, dan $40 \mathrm{~cm}$ serta tinggi web 0,75 terhadap tinggi penampangnya.

Panjang balok kayu diambil bervariasi dari 1m - 8m, dan dipelajari pula sebaliknya pada panjang berapakah pengaruh lendutan geser ketika mencapai harga $10 \%$, $5 \%$, dan 2\%. Dari analisis ini diperoleh beberapa grafik yang dapat digunakan untuk semua jenis kayu. Dengan mengetahui harga modulus elastisitas dan modulus geser kayu dapat diperoleh besarnya pengaruh lendutan akibat gaya geser untuk balok berpenampang I dan persegi panjang dengan berbagai panjang balok. 


\section{MODULUS ELASTISITAS DAN MODULUS GESER KAYU}

Mengingat belum banyak jenis kayu yang memiliki data eksperimental modulus gesernya, maka diambil 31 jenis kayu luar (Wood Handbook 2010) dan 3 jenis kayu Indonesia yaitu, Akasia, Meranti, dan Kruing (Tjondro 2007). Sebanyak 34 jenis kayu diurutkan berdasarkan rasio antara modulus geser dengan modulus elastisitasnya (G/E) dari harga terkecil sampai terbesar (Tabel 1).

Tabel 1. Rasio antara modulus geser dengan modulus elastisitas.

\begin{tabular}{|c|l|c|c|c|c|l|c|c|c|}
\hline No & Jenis Kayu & $\mathrm{E}_{\mathrm{L}}$ & $\mathrm{G}_{\mathrm{L}}$ & $\mathrm{G}_{\mathrm{L}} / \mathrm{E}_{\mathrm{L}}$ & No & Jenis Kayu & $\mathrm{E}_{\mathrm{L}}$ & $\mathrm{G}_{\mathrm{L}}$ \\
$(\mathrm{MPa})$ & $(\mathrm{MPa})$ & & $\mathrm{G}_{\mathrm{L}} / \mathrm{E}_{\mathrm{L}}$ \\
\hline 1 & Hemlock & 11300 & 396 & 0,035 & 18 & Douglas-fir & 13400 & 951 & 0,071 \\
\hline 2 & Pine, pond & 12100 & 575 & 0,047 & 19 & Yellow-poplar & 10900 & 785 & 0,072 \\
\hline 3 & Pine, lod. & 9200 & 437 & 0,048 & 20 & Walnut black & 11600 & 853 & 0,073 \\
\hline 4 & Pine, western & 10100 & 505 & 0,050 & 21 & Sweetgum & 11300 & 848 & 0,075 \\
\hline 5 & Basswood & 10100 & 515 & 0,051 & 22 & Pine, loblolly & 12300 & 1002 & 0,081 \\
\hline 6 & Pine, slash & 13700 & 740 & 0,054 & 23 & Oak, red & 13100 & 1113 & 0,085 \\
\hline 7 & Akasia & 11043 & 600 & 0,054 & 24 & Oak, white & 12300 & 1058 & 0,086 \\
\hline 8 & Meranti & 13070 & 750 & 0,057 & 25 & Maple, sugar & 12600 & 1096 & 0,087 \\
\hline 9 & Baldcypress & 9900 & 579 & 0,058 & 26 & Cedar, west. & 7700 & 667 & 0,087 \\
\hline 10 & Kruing & 14868 & 900 & 0,060 & 27 & Pine, red & 11200 & 991 & 0,088 \\
\hline 11 & Spruce, sitka & 9900 & 619 & 0,062 & 28 & Ash, white & 12000 & 1116 & 0,093 \\
\hline 12 & Cottonwood & 9400 & 602 & 0,064 & 29 & Maple, red & 11300 & 1170 & 0,103 \\
\hline 13 & Fir, subalpine & 8900 & 570 & 0,064 & 30 & Pine, sugar & 8200 & 972 & 0,118 \\
\hline 14 & Pine, longleaf & 13700 & 897 & 0,065 & 31 & Spruce, Engel. & 8900 & 1086 & 0,122 \\
\hline 15 & Larch, west. & 12900 & 851 & 0,066 & 32 & Cherry, black & 10300 & 1257 & 0,122 \\
\hline 16 & Birch, yellow & 13900 & 987 & 0,071 & 33 & P. ponderosa & 8900 & 1126 & 0,126 \\
\hline 17 & Redwood & 9200 & 658 & 0,071 & 34 & Cedar, north. & 5500 & 1092 & 0,198 \\
\hline
\end{tabular}

\section{PERSAMAAN LENDUTAN BALOK}

Lendutan total akibat momen dan gaya geser dihitung ditengah bentang balok dengan beban terpusat di tengahnya (Gambar 1). Persamaan lendutan total untuk balok penampang persegi panjang dan penampang I (Persamaan 2, 3, dan 4):

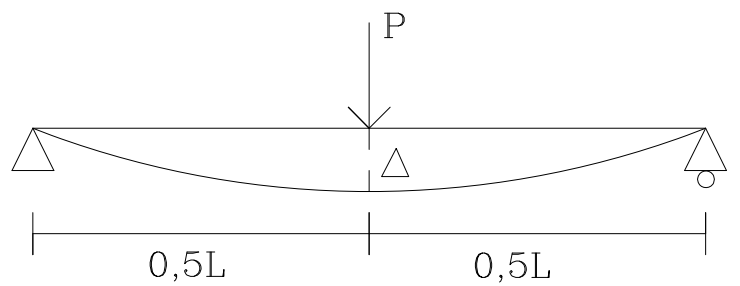

\section{Gambar 1. Lendutan di tengah bentang}

Persamaan umum lendutan akibat momen lentur dan gaya geser dengan beban di tengah bentang adalah: 


$$
\begin{aligned}
& \Delta=\Delta_{\mathrm{L}}+\Delta_{\mathrm{G}} \\
& \Delta=\frac{\text { P.L }}{48 . \mathrm{E} \cdot \mathrm{I}}+\frac{0,25 \cdot \mathrm{P} \cdot \mathrm{L}}{\text { F.G }}
\end{aligned}
$$

dimana:

$$
\begin{array}{ll}
\Delta & =\text { lendutan total }(\mathrm{mm}) \\
\Delta_{\mathrm{L}} & =\text { lendutan akibat momen lentur }(\mathrm{mm}) \\
\Delta_{\mathrm{G}} & =\text { lendutan akibat gaya geser }(\mathrm{mm}) \\
\mathrm{P} & =\text { beban }(\mathrm{N}) \\
\mathrm{L} & =\text { panjang bentang balok }(\mathrm{mm}) \\
\mathrm{E} & =\text { modulus elastisitas kayu }(\mathrm{MPa}) \\
\mathrm{F} & =\text { luas penampang efektif }\left(\mathrm{mm}^{2}\right) \\
\mathrm{G} & =\text { modulus geser kayu }(\mathrm{MPa})
\end{array}
$$

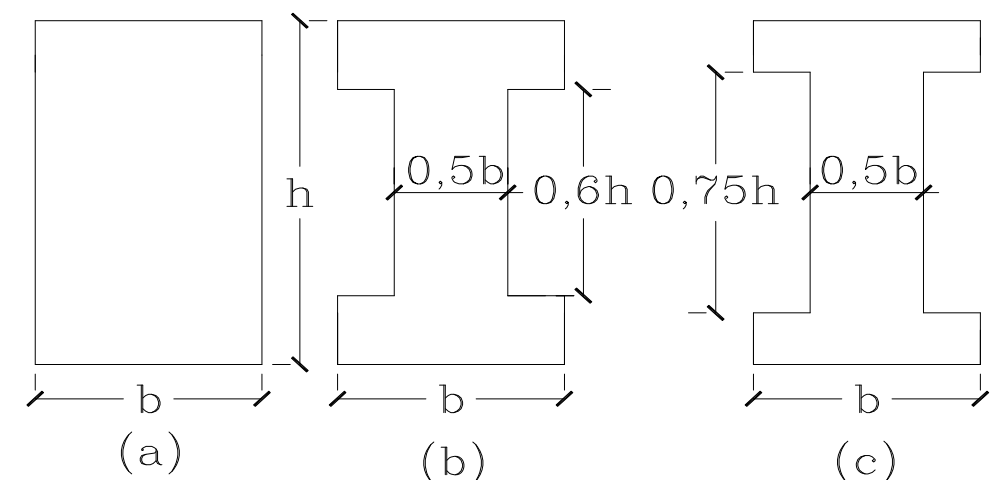

Gambar 2: Penampang balok (a). Persegi empat (b). I dengan tinggi web 0,6h (c). I dengan tinggi web $0,75 \mathrm{~h}$.

Jika balok penampang persegi panjang dengan lebar b dan tinggi h (Gambar 2a) maka persamaan lendutan akibat momen lentur dan gaya geser adalah:

$$
\Delta=\frac{\text { P.L } \mathrm{L}^{3}}{\text { 4.E.b.h } \mathrm{h}^{3}}+\frac{\text { 0,3.P.L }}{\text { b.h.G }}
$$

Jika balok penampang I dengan tinggi web 0,6 h (Gambar 2b) maka persamaan lendutan akibat momen lentur dan gaya geser adalah:

$$
\Delta=\frac{125 . P \cdot \mathrm{L}^{3}}{446 \cdot \mathrm{E} \cdot \mathrm{b} \cdot \mathrm{h}^{3}}+\frac{5 \cdot \mathrm{P} \cdot \mathrm{L}}{6 \cdot \mathrm{b} \cdot \mathrm{h} \cdot \mathrm{G}}
$$


Jika balok penampang I dengan tinggi web $0,75 \mathrm{~h}$ (Gambar 2c) maka persamaan lendutan akibat momen lentur dan gaya geser adalah:

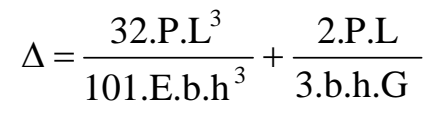

\section{HASIL ANALISIS}

\subsection{Analisis Lendutan Balok Kayu dengan Penampang Persegi Panjang}

Besarnya persentase lendutan geser terhadap lendutan totalnya untuk balok penampang persegi panjang didapat dari persamaan (2) dengan bantuan MathCAD. Lendutan dihitung untuk kayu Hemlock yang mempunyai harga G/E terkecil yaitu 0,035, kemudian kayu Indonesia yaitu kayu Akasia dengan rasio sebesar 0,054, dan kayu Cedar Northern White dengan G/E terbesar 0,198.

Hasil perhitungan menunjukan bahwa lebar penampang balok tidak mempengaruhi harga lendutan geser/lendutan total $\left(\Delta_{\mathrm{G}} / \Delta\right)$. Kayu Hemlock yang mempunyai harga G/E kecil dengan tinggi $40 \mathrm{~cm}$ dan panjang balok $1 \mathrm{~m}$ dipengaruhi lendutan akibat geser sebesar 84,6 \% terhadap lendutan totalnya. Sedangkan pengaruh geser akan kecil sebesar $2 \%$ jika balok mencapai panjang 16,2 $\mathrm{m}$ dengan tinggi penampang $40 \mathrm{~cm}$.

Tabel 2. Kayu Hemlock dengan penampang persegi panjang.

\begin{tabular}{|c|c|c|c|c|c|c|c|}
\hline \multirow{3}{*}{$\begin{array}{l}\text { Tinggi } \\
\text { Balok } \\
\text { (cm) }\end{array}$} & \multirow{2}{*}{\multicolumn{4}{|c|}{$\begin{array}{c}\text { Lendutan Geser/Lendutan Total (\%) } \\
\text { dengan Panjang Balok }\end{array}$}} & \multicolumn{3}{|c|}{ Lendutan Geser/Lend. Total } \\
\hline & & & & & $10 \%$ & $5 \%$ & $2 \%$ \\
\hline & $1 \mathrm{~m}$ & $2 \mathrm{~m}$ & $4 \mathrm{~m}$ & $8 \mathrm{~m}$ & \multicolumn{3}{|c|}{ Panjang Balok (m) } \\
\hline 10 & 25,5 & 7,9 & 2,1 & 0,5 & 1,75 & 2,6 & 4,1 \\
\hline 20 & 57,8 & 25,5 & 7,9 & 2,1 & 3,5 & 5,2 & 8,2 \\
\hline 30 & 75,5 & 43,5 & 16,2 & 4,6 & 5,25 & 7,8 & 12,3 \\
\hline 40 & 84,6 & 57,8 & 25,5 & 7,9 & 7 & 10,4 & 16,2 \\
\hline
\end{tabular}

Tabel 3. Kayu Akasia dengan penampang persegi panjang.

\begin{tabular}{|c|c|c|c|c|c|c|c|}
\hline \multirow{3}{*}{$\begin{array}{l}\text { Tinggi } \\
\text { Balok } \\
\text { (cm) }\end{array}$} & \multirow{2}{*}{\multicolumn{4}{|c|}{$\begin{array}{c}\text { Lendutan Geser/Lendutan Total (\%) } \\
\text { dengan Panjang Balok }\end{array}$}} & \multicolumn{3}{|c|}{ Lendutan Geser/Lend. Total } \\
\hline & & & & & $10 \%$ & $5 \%$ & $2 \%$ \\
\hline & $1 \mathrm{~m}$ & $2 \mathrm{~m}$ & $4 \mathrm{~m}$ & $8 \mathrm{~m}$ & \multicolumn{3}{|c|}{ Panjang Balok (m) } \\
\hline 10 & 18,1 & 5,2 & 1,4 & 0,3 & 1,4 & 2,05 & 3,3 \\
\hline 20 & 46,9 & 18,1 & 5,2 & 1,4 & 2,8 & 4,1 & 6,6 \\
\hline 30 & 66,5 & 33,2 & 11,1 & 3 & 4,2 & 6,15 & 9,9 \\
\hline 40 & 77,9 & 46,9 & 18,1 & 5,2 & 5,6 & 8,2 & 13,2 \\
\hline
\end{tabular}


Kayu Akasia mempunyai harga G/E sebesar 0,054 lebih besar dari kayu Hemlock (Tabel 3). Pengaruh lendutan geser terhadap lendutan total harganya masih besar, contoh untuk balok dengan tinggi 40 cm, panjang 1m harganya 77,9 \%. Semakin panjang balok pengaruh gaya geser terhadap lendutan total makin kecil, sedangkan semakin tinggi penampang balok semakin besar pengaruh gesernya. Kayu dari Indonesia lainnya seperti Meranti dan Kruing dengan harga G/E masing-masing sebesar 0,057 dan 0,06 akan mempunyai harga persentase yang hampir sama dengan kayu akasia.

Kayu Cedar Northern White mempunyai harga G/E besar yaitu 0,198. Sebagian besar jenis kayu luar maupun kayu Indonesia mempunyai harga G/E dibawah 0,198. Dengan harga sebesar ini, pengaruh lendutan geser masih cukup besar untuk diperhitungkan (Tabel 4). Perhitungan menunjukan semakin besar harga G/E semakin kecil pengaruh gaya geser terhadap lendutan balok.

Tabel 4. Kayu Cedar Northern White dengan penampang persegi panjang.

\begin{tabular}{|c|c|c|c|c|c|c|c|}
\hline \multirow{3}{*}{$\begin{array}{l}\text { Tinggi } \\
\text { Balok } \\
\text { (cm) }\end{array}$} & \multirow{2}{*}{\multicolumn{4}{|c|}{$\begin{array}{c}\text { Lendutan Geser/Lendutan Total (\%) } \\
\text { dengan Panjang Balok }\end{array}$}} & \multicolumn{3}{|c|}{ Lendutan Geser/Lend. Total } \\
\hline & & & & & $10 \%$ & $5 \%$ & $2 \%$ \\
\hline & $1 \mathrm{~m}$ & $2 \mathrm{~m}$ & $4 \mathrm{~m}$ & $8 \mathrm{~m}$ & \multicolumn{3}{|c|}{ Panjang Balok (m) } \\
\hline 10 & 5,7 & 1,5 & 0,4 & 0,1 & 0,7 & 1,08 & 1,7 \\
\hline 20 & 19,5 & 5,7 & 1,5 & 0,4 & 1,4 & 2,15 & 3,4 \\
\hline 30 & 35,2 & 12 & 3,3 & 0,8 & 2,1 & 3,23 & 5,1 \\
\hline 40 & 49,2 & 19,5 & 5,7 & 1,5 & 2,8 & 4,3 & 6,8 \\
\hline
\end{tabular}

\subsection{Analisis Lendutan Balok Kayu dengan Penampang I}

Perhitungan lendutan akibat lentur dan geser untuk penampang balok I menggunakan persamaan (3) dan (4). Penampang balok I dengan variasi (1). Lebar web 0,5 b dan tinggi web 0,6 h. (2). Lebar web 0,5 b dan tinggi web 0,75 h (Gambar 2b, 2c). Lebar balok tidak berpengaruh pada persentase besarnya gaya geser terhadap lendutan total pada penampang persegi panjang maupun penampang I. Kayu yang ditinjau adalah kayu Hemlock, Meranti dan kayu Kruing.

Pengaruh gaya geser pada balok penampang I lebih besar dari pada balok penampang persegi panjang untuk jenis kayu yang sama. Sedangkan untuk tinggi web yang lebih besar dengan ukuran tinggi balok yang sama, pengaruh gaya geser lebih kecil. Kayu dengan harga rasio G/E kecil seperti Hemlock terlihat pengaruh gesernya sangat besar yaitu sekitar 90\% untuk tinggi balok $40 \mathrm{~cm}$ dan panjang $1 \mathrm{~m}$. Pengaruh geser semakin menghilang untuk panjang balok mencapai lebih dari 22 m (Tabel 5, Tabel 6). 
Tabel 5. Kayu Hemlock penampang I dengan tinggi web 0,6 h.

\begin{tabular}{|c|c|c|c|c|c|c|c|}
\hline Tinggi & \multicolumn{4}{|c|}{ Lendutan Geser/Lendutan Total (\%) } & \multicolumn{3}{|c|}{ Lendutan Geser/Lend. Total } \\
\cline { 4 - 8 } $\begin{array}{c}\text { Balok } \\
(\mathrm{cm})\end{array}$ & \multicolumn{3}{|c|}{ dengan Panjang Balok } & \multicolumn{2}{c|}{$10 \%$} & $5 \%$ & $2 \%$ \\
\hline & $1 \mathrm{~m}$ & $2 \mathrm{~m}$ & $4 \mathrm{~m}$ & $8 \mathrm{~m}$ & \multicolumn{3}{c|}{ Panjang Balok (m) } \\
\hline 20 & 77,2 & 45,9 & 17,5 & 5 & 5,6 & 8 & 11 \\
\hline 30 & 88,4 & 65,6 & 32,3 & 10,7 & 8,4 & 12 & 16,5 \\
\hline 40 & 93,1 & 77,2 & 45,9 & 17,5 & 11,2 & 16 & 22 \\
\hline
\end{tabular}

Tabel 6. Kayu Hemlock penampang I dengan tinggi web 0,75 h

\begin{tabular}{|c|c|c|c|c|c|c|c|}
\hline \multirow{3}{*}{$\begin{array}{l}\text { Tinggi } \\
\text { Balok } \\
\text { (cm) }\end{array}$} & \multirow{2}{*}{\multicolumn{4}{|c|}{$\begin{array}{c}\text { Lendutan Geser/Lendutan Total (\%) } \\
\text { dengan Panjang Balok }\end{array}$}} & \multicolumn{3}{|c|}{ Lendutan Geser/Lend. Total } \\
\hline & & & & & $10 \%$ & $5 \%$ & $2 \%$ \\
\hline & $1 \mathrm{~m}$ & $2 \mathrm{~m}$ & $4 \mathrm{~m}$ & $8 \mathrm{~m}$ & \multicolumn{3}{|c|}{ Panjang Balok (m) } \\
\hline 20 & 70,6 & 37,5 & 13,1 & 3,6 & 4,8 & 6,8 & 10,8 \\
\hline 30 & 84,4 & 57,5 & 25,2 & 7,8 & 7,2 & 10,2 & 16,2 \\
\hline 40 & 90,6 & 70,6 & 37,5 & 13,1 & 9,6 & 13,6 & 21,6 \\
\hline
\end{tabular}

Tabel 7. Kayu Meranti penampang I dengan tinggi web 0,6 h

\begin{tabular}{|c|c|c|c|c|c|c|c|}
\hline Tinggi & \multicolumn{4}{|c|}{ Lendutan Geser/Lendutan Total (\%) } & \multicolumn{3}{|c|}{ Lendutan Geser/Lend. Total } \\
\cline { 4 - 8 } $\begin{array}{c}\text { Balok } \\
\text { (cm) }\end{array}$ & \multicolumn{3}{|c|}{ dengan Panjang Balok } & \multicolumn{3}{c|}{$10 \%$} & \multicolumn{2}{c|}{$5 \%$} & $2 \%$ \\
\hline & $1 \mathrm{~m}$ & $2 \mathrm{~m}$ & $4 \mathrm{~m}$ & $8 \mathrm{~m}$ & \multicolumn{3}{c|}{ Panjang Balok (m) } \\
\hline 20 & 67,5 & 34,1 & 11,5 & 3,1 & 4,4 & 6,2 & 10 \\
\hline 30 & 82,3 & 53,8 & 22,6 & 6,8 & 6,6 & 9,3 & 15 \\
\hline 40 & 89,2 & 67,5 & 34,1 & 11,5 & 8,8 & 12,4 & 20 \\
\hline
\end{tabular}

Tabel 8. Kayu Meranti penampang I dengan tinggi web 0,75 h

\begin{tabular}{|c|c|c|c|c|c|c|c|}
\hline Tinggi & \multicolumn{3}{|c|}{ Lendutan Geser/Lendutan Total (\%) } & \multicolumn{3}{|c|}{ Lendutan Geser/Lend. Total } \\
\cline { 4 - 8 } $\begin{array}{c}\text { Balok } \\
(\mathrm{cm})\end{array}$ & \multicolumn{3}{|c|}{ dengan Panjang Balok } & \multicolumn{3}{c|}{$10 \%$} & \multicolumn{2}{c|}{$5 \%$} & $2 \%$ \\
\hline & $1 \mathrm{~m}$ & $2 \mathrm{~m}$ & $4 \mathrm{~m}$ & $8 \mathrm{~m}$ & \multicolumn{3}{c|}{ Panjang Balok (m) } \\
\hline 20 & 59,5 & 26,8 & 8,4 & 2,2 & 3,65 & 5,3 & 8,4 \\
\hline 30 & 76,7 & 45,2 & 17,1 & 4,9 & 5,45 & 7,65 & 12,6 \\
\hline 40 & 85,4 & 59,5 & 26,8 & 8,4 & 7,3 & 10,6 & 16,8 \\
\hline
\end{tabular}

Perhitungan pengaruh gaya geser pada kayu Meranti masih menunjukan harga besar. Kayu Meranti dan kayu Kruing mempunyai harga G/E yang hampir sama yaitu masing-masing sebesar 0,057 dan 0,06, akan menghasilkan besar pengaruh yang hampir sama pula. Perhitungan untuk kayu Kruing dengan tinggi web 0,6 h ditunjukan dengan grafik (Gambar 3).

Kayu dengan G/E besar seperti Kayu Cedar Northern White memberi pengaruh gaya geser lebih kecil dibandingkan dengan kayu yang mempunyai G/E kecil baik untuk penampang I maupun persegi panjang pada ukuran penampang yang sama. Meskipun kayu Cedar Northern White mempunyai G/E jauh lebih besar dibandingkan dengan kayu 
lainnya, harga pengaruh geser masih cukup besar untuk balok pendek. Pengaruh geser akan hilang jika panjang balok mencapai lebih dari $10 \mathrm{~m}$ (Tabel 8, 9).

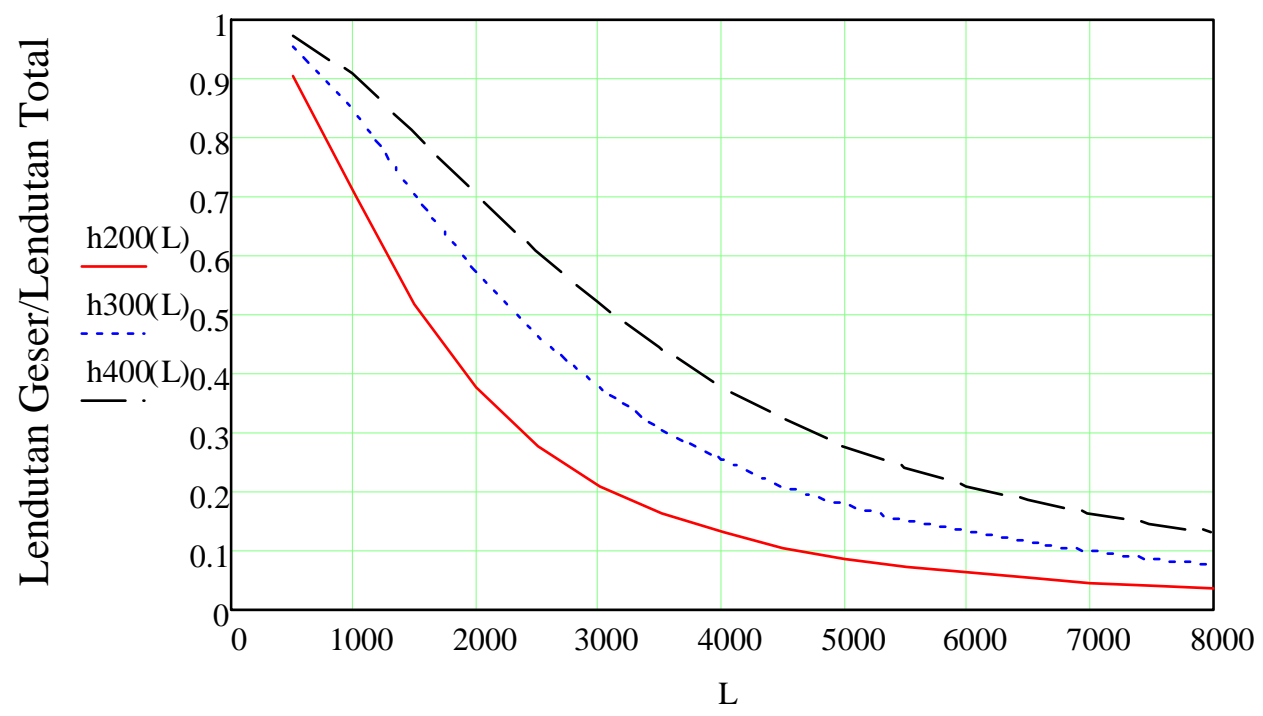

Panjang Balok (mm)

Gambar 3. Grafik hubungan antara panjang balok dengan lendutan geser/ lendutan total untuk tinggi penampang $200 \mathrm{~mm}$ - $400 \mathrm{~mm}$.

Tabel 8. Kayu Cedar White penampang I dengan tinggi web 0,6 h

\begin{tabular}{|c|c|c|c|c|c|c|c|}
\hline Tinggi & \multicolumn{3}{|c|}{$\begin{array}{c}\text { Lendutan Geser/Lendutan Total (\%) } \\
\text { Balok }\end{array}$} & \multicolumn{3}{|c|}{ dengan Panjang Balok } & \multicolumn{3}{c|}{ Lendutan Geser/Lend. Total } \\
\cline { 2 - 8 }$(\mathrm{cm})$ & $1 \mathrm{~m}$ & $2 \mathrm{~m}$ & $4 \mathrm{~m}$ & $8 \mathrm{~m}$ & \multicolumn{3}{c|}{ Panjang Balok (m) } \\
\hline 20 & 37,5 & 13 & 3,6 & 0,9 & 2,3 & 3,4 & 5,4 \\
\hline 30 & 57,4 & 25,2 & 7,8 & 2,1 & 3,65 & 5,1 & 8,1 \\
\hline 40 & 70,6 & 37,5 & 13 & 3,6 & 4,6 & 6,8 & 10,8 \\
\hline
\end{tabular}

Tabel 9. Kayu Cedar White penampang I dengan tinggi web 0,75 h

\begin{tabular}{|c|c|c|c|c|c|c|c|}
\hline \multirow{2}{*}{$\begin{array}{c}\text { Tinggi } \\
\text { Balok }\end{array}$} & \multicolumn{4}{|c|}{$\begin{array}{c}\text { Lendutan Geser/Lendutan Total (\%) } \\
\text { dengan Panjang Balok }\end{array}$} & \multicolumn{3}{|c|}{ Lendutan Geser/Lend. Total } \\
\cline { 5 - 8 }$(\mathrm{cm})$ & $1 \mathrm{~m}$ & $2 \mathrm{~m}$ & $4 \mathrm{~m}$ & $8 \mathrm{~m}$ & \multicolumn{3}{|c|}{ Panjang Balok (m) } \\
\cline { 2 - 8 } & 29,8 & 9,6 & 2,6 & 0,7 & 2 & 2,8 & 4,6 \\
\hline 20 & 48,8 & 19,3 & 5,6 & 1,5 & 3 & 4,2 & 6,9 \\
\hline 30 & 62,9 & 29,8 & 9,6 & 2,6 & 4 & 5,6 & 9,2 \\
\hline 40 & & & & & & \\
\hline
\end{tabular}

\subsection{Analisis Lendutan Akibat Geser untuk Semua Jenis Kayu}

Dari perhitungan 31 jenis kayu luar dan 3 jenis kayu dari Indonesia diperoleh persentase pengaruh lendutan geser untuk berbagai harga: G/E, panjang balok, bentuk 
penampang, dan tinggi balok. Kemudian perhitungan dikembangkan dengan bantuan MathCAD untuk semua jenis kayu, mengingat faktor dominannya adalah harga modulus geser dan modulus elastisitas kayu. Kayu yang sudah diketahui harga modulusnya mempunyai harga rasio modulus geser dengan modulus elastisitas antara 0,035 - 0,2. Pada studi analisis ini diambil harga G/E sebesar 0,04 - 0,2 dan ditampilkan dalam bentuk grafik. Dengan mengetahui harga G/E kayu, dari grafik hasil studi bisa didapatkan harga persentase pengaruh lendutan akibat gaya geser terhadap lendutan totalnya. Penggunaan grafik (gambar 4 - 11) mempunyai batasan yaitu (1).

Lendutan di hitung berdasarkan beban di tengah bentang dengan balok di atas dua tumpuan. (2). Penampang balok persegi panjang dengan tinggi $20 \mathrm{~cm}$ (Gambar 4 dan 5). (3). Penampang balok persegi panjang dengan tinggi $40 \mathrm{~cm}$ (Gambar 6 dan 7). (4). Penampang balok I dengan tinggi web 0,6 h dan tinggi penampang $40 \mathrm{~cm}$ (Gambar 8 dan 9). (5). Penampang balok I dengan tinggi web $0,75 \mathrm{~h}$ dan tinggi penampang $30 \mathrm{~cm}$ (Gambar 10 dan 11). Grafik hasil studi ini diharapkan bisa memberikan gambaran seberapa besar pengaruh gaya geser terhadap lendutan total kayu dan memperhitungkannya dalam analisa struktur khususnya pada struktur kayu.

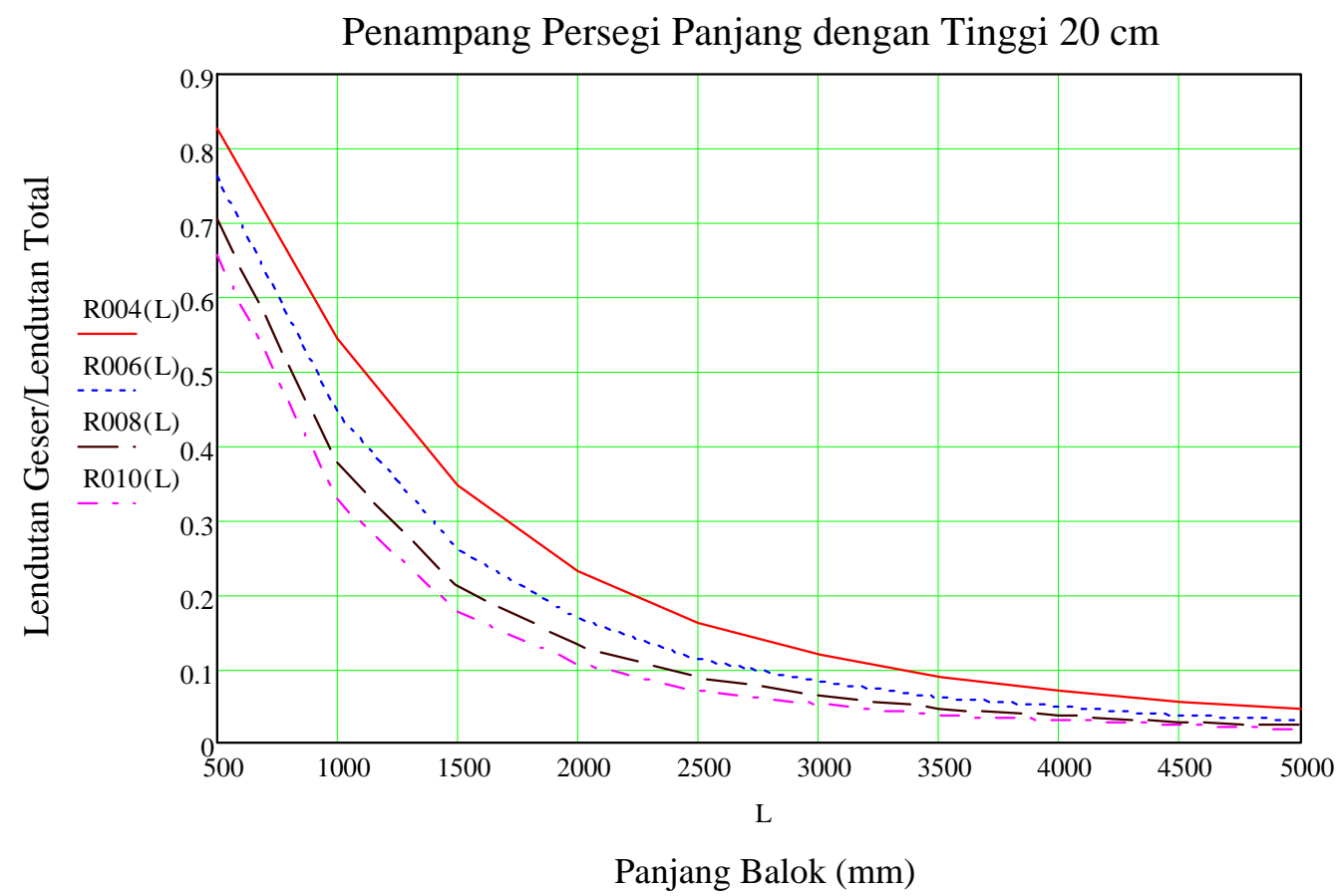

Gambar 4. Grafik hubungan antara panjang balok dengan lendutan geser / lendutan total untuk G/E 0,04-0,1. 


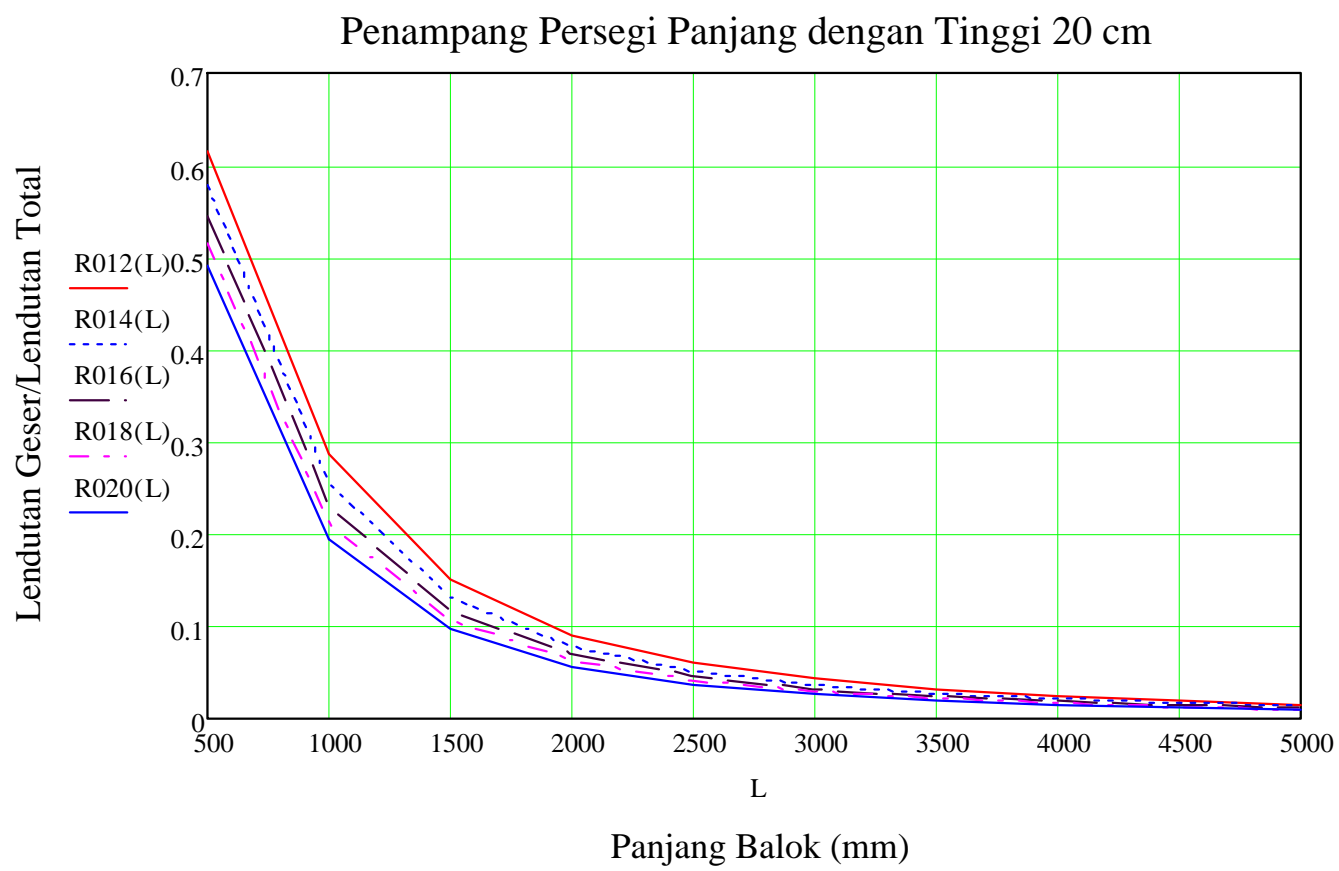

Gambar 5. Grafik hubungan antara panjang balok dengan rasio lendutan geser/ lendutan total untuk G/E 0,12 - 0,2.

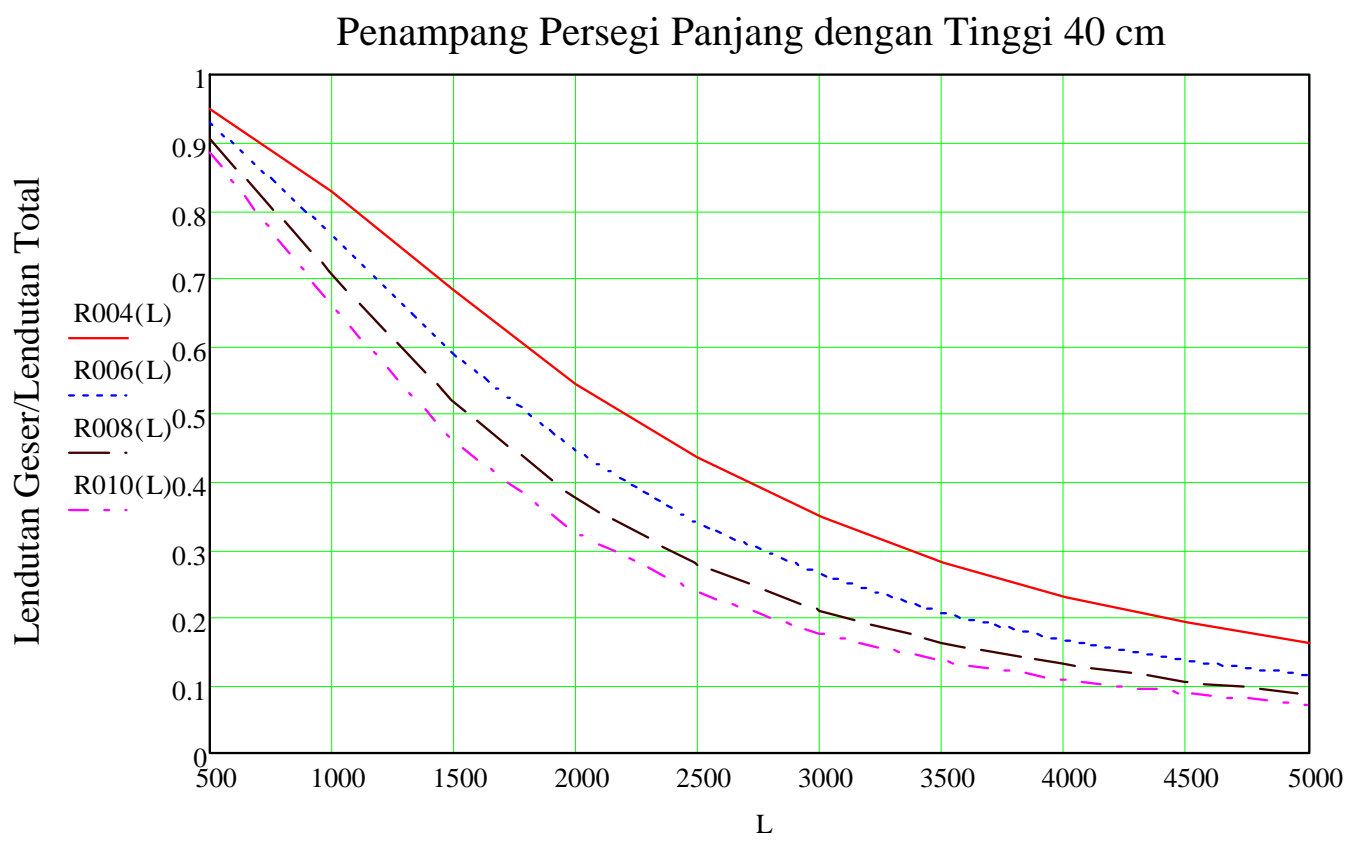

Panjang Balok (mm)

Gambar 6. Grafik hubungan antara panjang balok $(\mathrm{mm})$ dengan lendutan geser/lendutan total dengan G/E 0,04-0,1. 


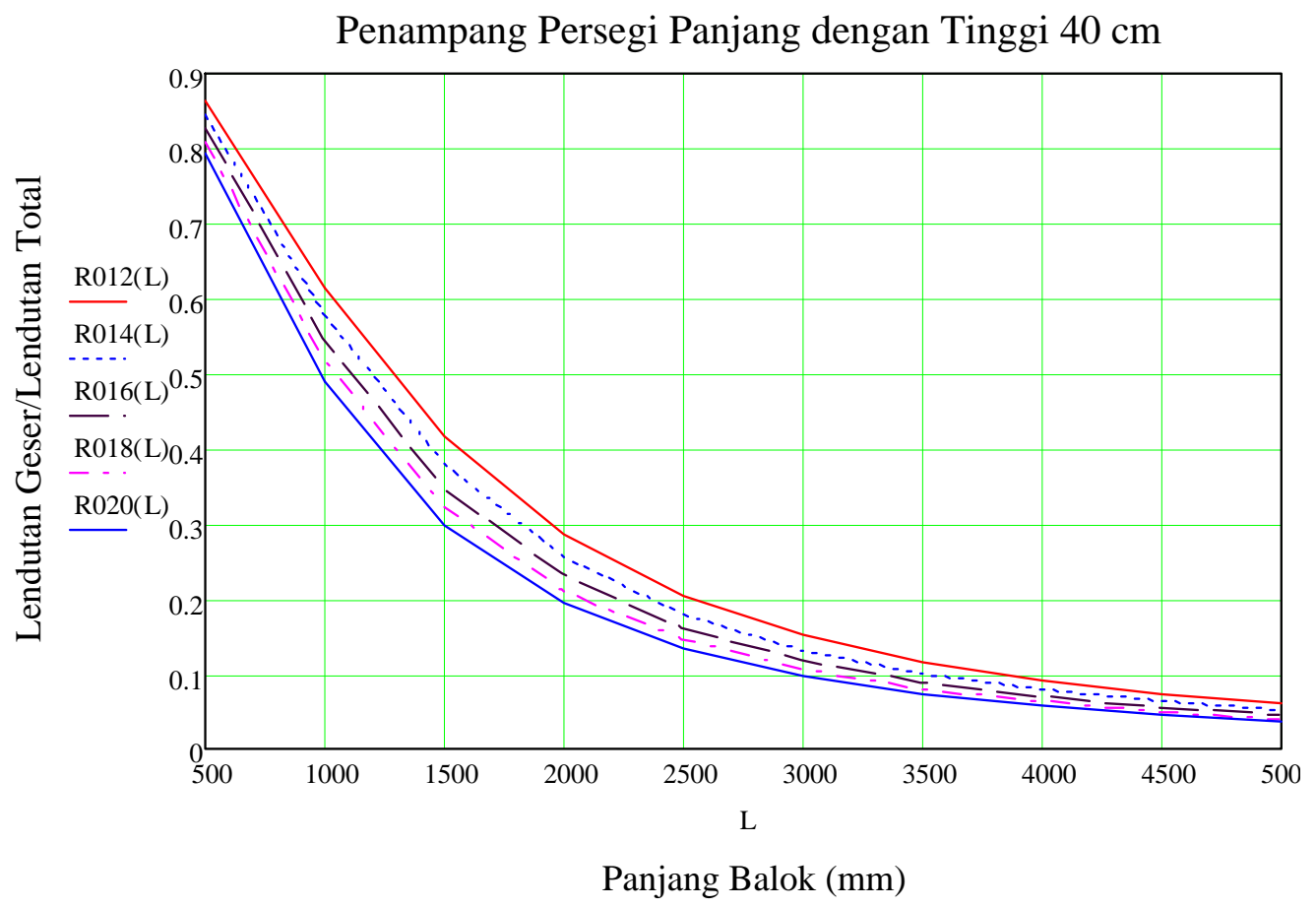

Gambar 7. Grafik hubungan antara panjang balok dengan lendutan geser/ lendutan total untuk G/E 0,12 - 0,2.

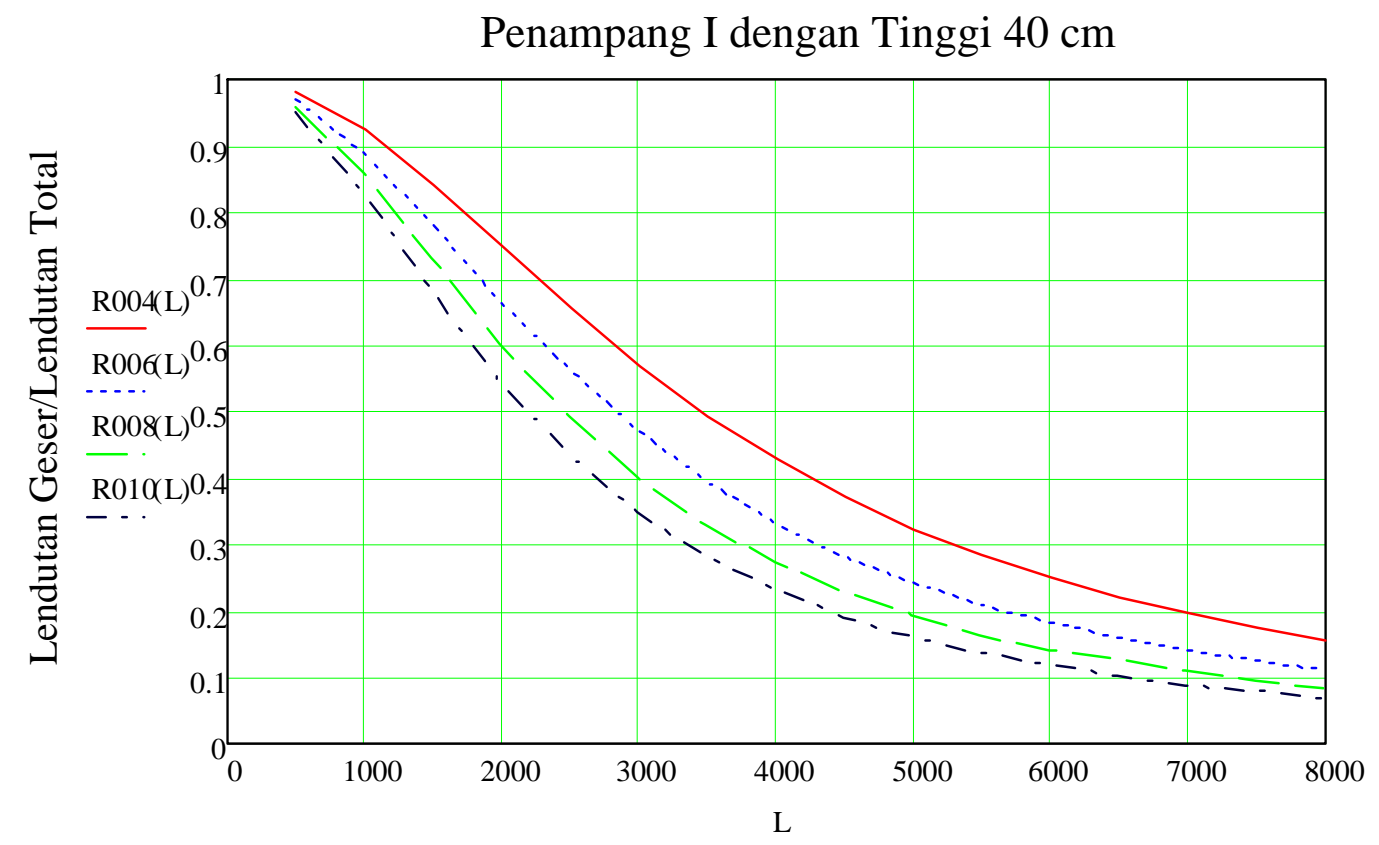

Panjang Balok (mm)

Gambar 8. Grafik hubungan antara panjang balok dengan lendutan geser/lendutan total untuk G/E 0,04 - 0,1 dan tinggi web 0,6 h. 


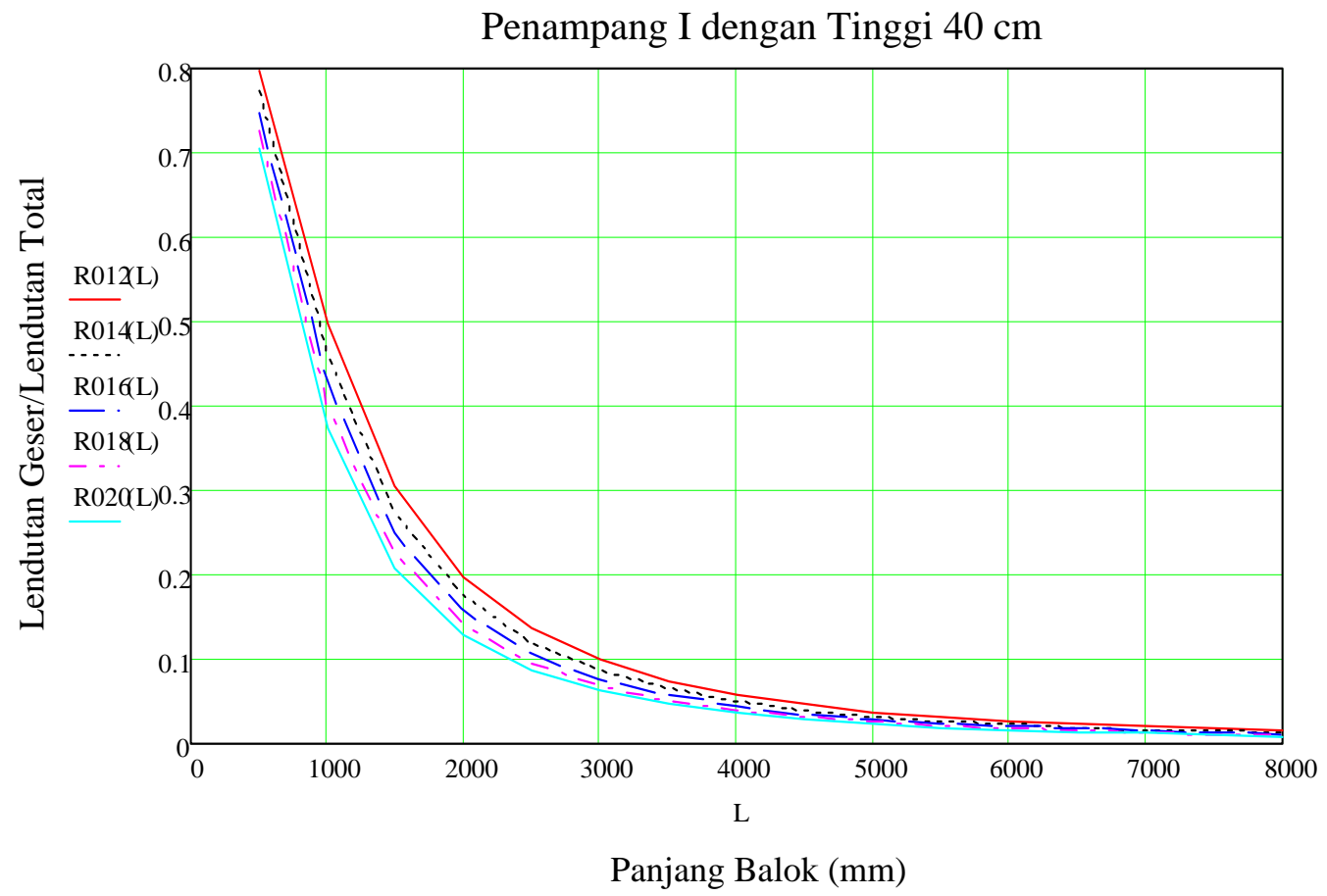

Gambar 9. Grafik hubungan antara panjang balok dengan lendutan geser/lendutan total untuk G/E 0,12 - 0,2 dan tinggi web 0,6 h.

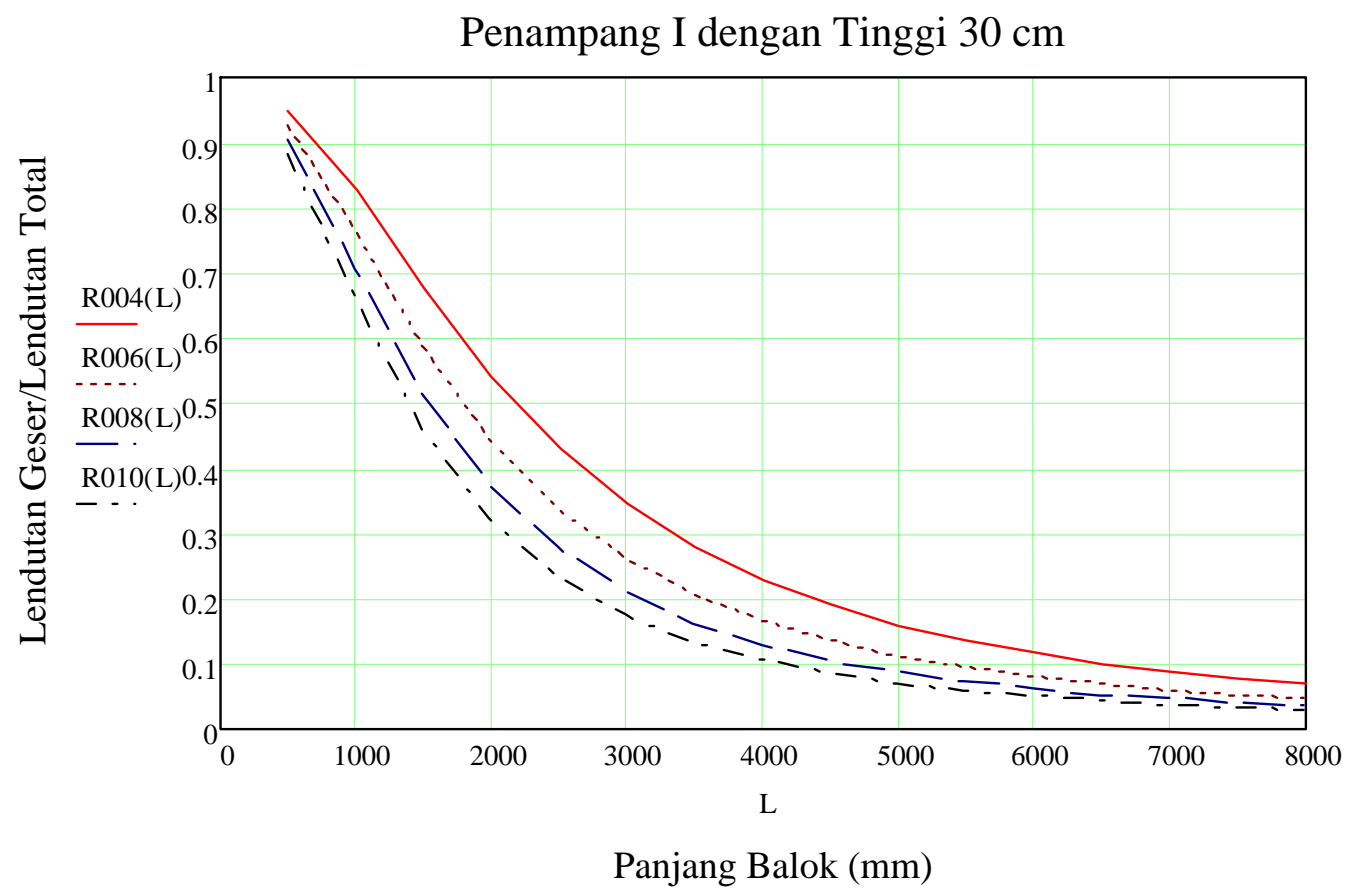

Gambar 10. Grafik hubungan antara panjang balok dengan lendutan geser/lendutan total untuk G/E 0,04-0,1 dan tinggi web 0,75 h. 


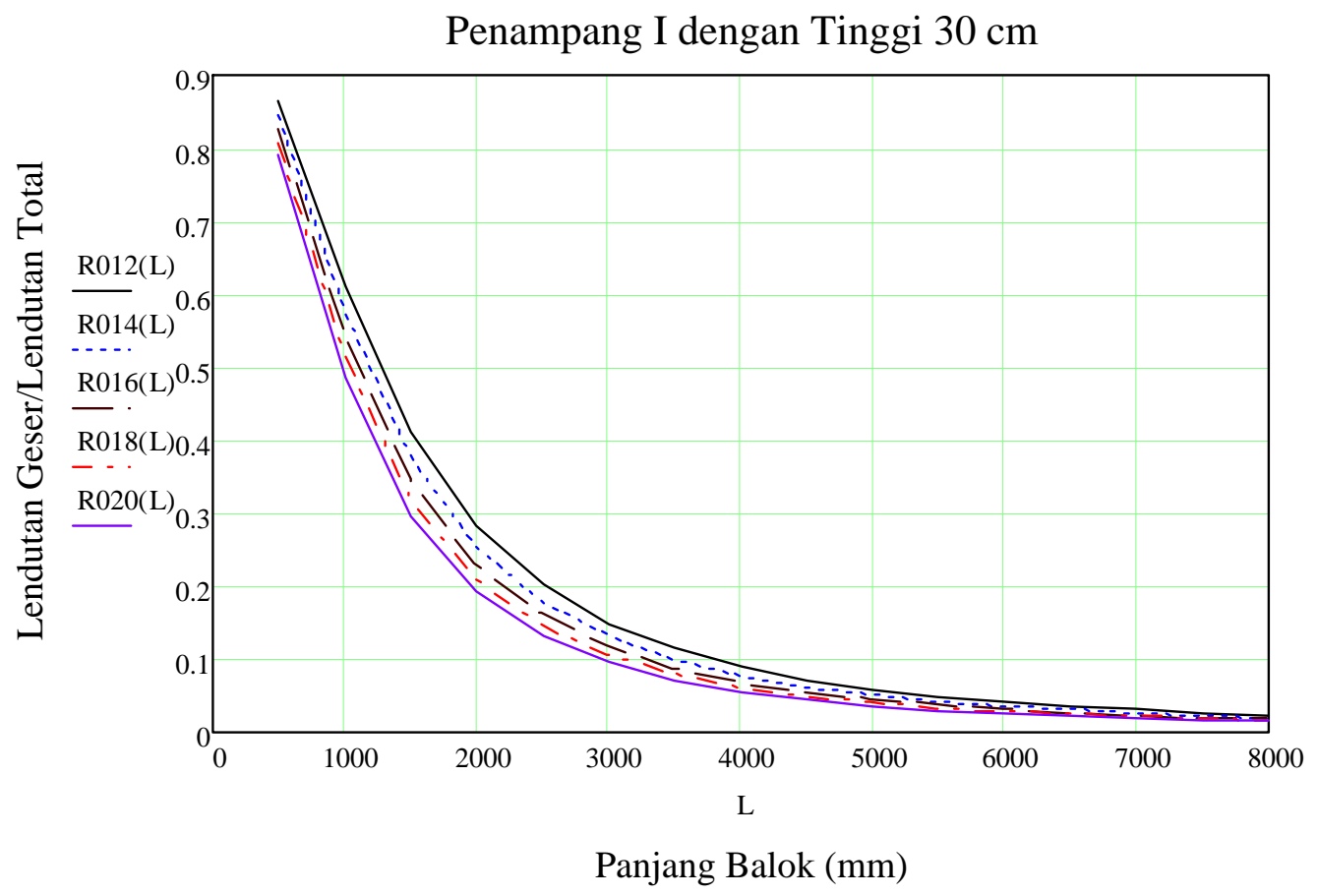

Gambar 11. Grafik hubungan antara panjang balok dengan lendutan geser/lendutan total untuk G/E 0,12 - 0,2 dan tinggi web $0,75 \mathrm{~h}$.

\section{KESIMPULAN}

Berdasarkan hasil analisis lendutan geser pada balok kayu, maka dapat diambil kesimpulan sebagai berikut:

1. Lebar penampang balok persegi panjang maupun penampang I tidak mempengaruhi besarnya pengaruh geser pada lendutan.

2. Semakin tinggi penampang balok I dan persegi panjang, semakin besar pengaruh lendutan geser terhadap lendutan totalnya.

3. Besarnya modulus geser/modulus elastisitas kayu menjadi faktor utama yang menentukan besarnya pengaruh akibat geser. Semakin besar harga G/E semakin kecil pengaruh lendutan gesernya. Selain itu semakin panjang balok semakin kecil pengaruh lendutan gesernya.

4. Penampang I dengan tinggi web 0,6 h mempunyai harga pengaruh geser terbesar dibandingkan dengan penampang I dengan tinggi web $0,75 \mathrm{~h}$ kemudian penampang persegi panjang.

5. Kayu dengan harga $\mathrm{G} / \mathrm{E}$ rendah seperti kayu Hemlock $(\mathrm{G} / \mathrm{E}=0,035)$, pengaruh lendutan geser menjadi sangat besar. Salah satu contoh, 
6. Kayu dengan harga G/E tinggi seperti kayu Cedar Northern White $(\mathrm{G} / \mathrm{E}=0,198)$, pengaruh lendutan geser masih cukup besar. Penampang persegi panjang $40 \mathrm{~cm}$ dengan panjang $1 \mathrm{~m}$ pengaruhnya sebesar 49,2 \% sedangkan untuk panjang balok $4 \mathrm{~m}$ sebesar 5,7\% dan pengaruh geser akan hilang untuk panjang balok di atas $7 \mathrm{~m}$. Sebagian besar kayu mempunyai harga G/E jauh dibawah 0,2, berarti pengaruh gesernya akan hilang jauh di atas $7 \mathrm{~m}$.

7. Kayu Indonesia Akasia, Meranti, dan Kruing memiliki harga G/E hampir sama masing-masing sebesar 0,054, 0,057, dan 0,06. Pengaruh lendutan geser perlu diperhitungkan, contoh kayu akasia dengan tinggi penampang persegi panjang $40 \mathrm{~cm}$ dengan panjang $4 \mathrm{~m}$ sebesar 18,1 \%. Pengaruh lendutan geser akan hilang pada panjang di atas $13 \mathrm{~m}$.

8. Beberapa grafik hasil studi analisis ini dapat dipergunakan untuk semua jenis kayu sehingga dapat memperkirakan berapa besar pengaruh geser dalam menganalisis struktur kayu.

\section{DAFTAR PUSTAKA}

1. Forest Product Laboratory, (2010). Wood Handbook, Wood as an Engineering Material,USA: USDA.

2. Gere JM., (2001). Mechanics of Materials, $5^{\text {th }}$ ed.USA: Brooks/Cole.

3. Tjondro. J.A., (2007). Perilaku Sambungan Kayu dengan Baut Tunggal Berpelat Sisi Baja akibat Beban Uni-Aksial Tarik (Disertasi), Universitas Katolik Parahyangan, Bandung. 